Poznańskie Studia Teologiczne 29(2015), s. 139-163. doi: $10.14746 /$ pst.2015.29.8

\author{
Piotr Ostański ${ }^{1}$ \\ Uniwersytet im. Adama Mickiewicza w Poznaniu \\ Wydział Teologiczny
}

\title{
Ocalenie jakby przez ogień (1 Kor 3,15). Czyściec z perspektywy Biblii i w refleksji teologicznej
}

Pytania o życie po śmierci nurtowały człowieka od zarania dziejów. Stawiały je także starożytne ludy mieszkające na Bliskim Wschodzie, w tym Izraelici².

Jest znamienne, że na kartach Pisma Świętego prawda o życiu pozagrobowym nie została podana od razu w formie ostatecznej, ale jest odsłaniana stopniowo:

- w najstarszych warstwach Biblii śmierć kończy definitywnie egzystencję człowieka i potem nie ma już żadnej formy kontynuacji życia, dlatego zarówno nagroda za dobre życie, jak i kara za grzech muszą się dokonać w ramach po-

\footnotetext{
${ }^{1}$ Ksiądz Piotr Ostański, ur. w 1952 r., sakrament kapłaństwa w 1977 r. w Poznaniu, kolejno wikariusz, kapelan szpitala wojewódzkiego i proboszcz. Doktorat 1990 r., habilitacja 2008 r. Od wielu lat związany z Papieskim Wydziałem Teologicznym w Poznaniu i Wydziałem Teologicznym Uniwersytetu im. Adama Mickiewicza w Poznaniu. Od 2014 r. pracuje na stanowisku profesora UAM. Autor m.in.: Bibliografia biblistyki polskiej. 1945-1999 (2002), Objawienie Jezusa Chrystusa. Praktyczny komentarz do Apokalipsy (2005), Bibliografia biblistyki polskiej. 2000-2009 (2010), Wierze w Boga Ojca wszechmogacego. Kazania katechizmowe (2014), Bibliografia biblistyki polskiej. 2010-2013/2014 (2015).

${ }^{2}$ Wybrana literatura tematu: G. Baran, Los człowieka po śmierci w wierzeniach ludów ościennych dawnego Izraela, „Scripturae Lumen” 2(2010), s. 137-159; B. Bibik, Wyobrażenia Platona o życiu pozagrobowym, „Nowy Filomata” 6(2002) 1, s. 13-26; A. Citlak, Kraina umartych w koncepcji starotestamentowej, rabinistycznej i greckiej, „Studia Teologiczne” 7(2004), s. 35-61; P. Lorek, Od ludzkiej przypadtości po boska karę. Śmierć i życie pozagrobowe Antiocha IV Epifanesa w wybranych pismach starożytnych, „Theologica Wratislaviensia” 3(2008), s. 23-29; M. Münnich, Przemiany pierwotnych wierzeń dotyczacych świata umartych $w$ Biblii hebrajskiej na tle wierzeń bliskowschodnich, „Roczniki Humanistyczne” 2(2003), s. 5-27; M. Otto, Koncepcja duszy $i$ świata pozagrobowego $w$,Odysei” Homera, w: Starożytność w wielu perspektywach. Materiaty ogólnopolskiej studenckiej konferencji naukowej, Bydgoszcz 23-24 kwietnia 2003 r., red. L. Mrozewicz, Bydgoszcz 2006, s. 35-41; M. Roszewski, Śmierć $i$ życie pozagrobowe w tradycjach pozabiblijnych i biblijnych Starego Testamentu. Zarys problemu, „Studia Teologiczno-Historyczne Śląska Opolskiego" 25(2005), s. 307-327; K. Sekita, Złote tabliczki orfickie. Życie po śmierci w wierzeniach starożytnych Greków, Warszawa 2011; M. Stuligrosz, Pindar o życiu po śmierci, „Acta Universitatis Wratislaviensis. Classica” 26(2005), s. 66-78; W. Szczerba, Śmierć i nie-śmiertelność w mitologii greckiej, „Theologica Wratislaviensia” 3(2008), s. 103-118.
} 
rządku doczesnego; takie rozwiązanie Izraelici uważali za wyraz porządku w świecie i przejaw mądrości Boga

- w nieco późniejszych tekstach biblijnych pojawia się koncepcja tajemniczego Szeolu, czyli miejsca, w którym zmarli wegetują w bliżej niesprecyzowa-

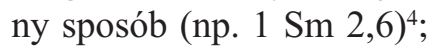

- dopiero u schyłku Starego Testamentu pojawia się właściwa idea życia pozagrobowego (np. 2 Mch 7,9; Mdr 2,23; 3,1-3) , a wraz z nią odpłata doczesna zostaje przeniesiona na życie po śmierci;

- w Nowym Testamencie prawda o życiu pozagrobowym oraz o nagrodzie i karze przybiera kształt wiary w powszechne zmartwychwstanie - „do życia” albo „do potępienia” (J 5,28-29) ${ }^{6}$.

Kościół uczy, że „każdy człowiek w swojej nieśmiertelnej duszy otrzymuje zaraz po śmierci wieczną zapłatę na sądzie szczegółowym, który polega na odniesieniu jego życia do Chrystusa i albo dokonuje się przez oczyszczenie, albo otwiera bezpośrednio wejście do szczęścia nieba, albo stanowi bezpośrednio potępienie na wieki"' $\mathrm{Z}$ tych słów wynika, że oprócz dwóch wiecznych stanów po śmierci, nieba i piekła, istnieje jeszcze trzeci stan, który nie jest ani szczęściem błogosławionych w niebie, ani odrzuceniem potępionych w piekle. Katechizm nazywa go „oczyszczeniem”, a teologia dogmatyczna - „czyśćcem” i odnosi do procesu oczyszczenia po śmierci z win, które uniemożliwiają człowiekowi uszczęśliwiające zjednoczenie z Bogiem. Jakkolwiek w sądzie szczegółowym rozstrzyga się los człowieka, niemniej jednak ten los nie musi się dopełnić natychmiast w momencie śmierci ${ }^{8}$.

O ile na temat nieba i piekła autorzy biblijni wypowiadają się otwarcie i szeroko, o tyle pouczenia dotyczące czyśćca są w Piśmie Świętym nieliczne i tylko

\footnotetext{
${ }^{3}$ Zob. C. Jakubiec, Zasada odpłaty, w: tenże, Księga Hioba, Poznań 1974, s. 250.

${ }^{4}$ Obraz Szeolu, czyli krainy, w której gromadzą się „,cienie” zmarłych, jest w Piśmie Świętym najczęściej pesymistyczny. Zob. M. Filipiak, Oczekiwanie nieśmiertelności w Starym Testamencie, „Roczniki Teologiczno-Kanoniczne” 25(1978) 1, s. 15; Zob. też A. Citlak, Kraina umartych w koncepcji starotestamentowej, rabinistycznej i greckiej, „Signa Temporis” 2004 7, s. 35-61; W. Kosior, The underworld or its ruler? Some remarks on the concept of Sheol in the Hebrew Bible, „The Polish Journal of Biblical Research” 13(2014) 25-26, s. 29-41; J. Lemański, Hebrajski Szeol na tle wyobrażeń eschatologicznych sqsiednich kultur, „Scripta Biblica et Orientalia” 3(2011), s. 67-98; M. Münnich, Świat umartych $w$ wyobrażeniach biblijnych środowisk madrościowych, „Theologica Wratislaviensia" 3(2008), s. 37-46.

${ }^{5}$ Zob. J. Homerski, Prawda o zmartwychwstaniu i życiu wiecznym w najmłodszych pismach natchnionych Starego Testamentu, „Roczniki Teologiczno-Kanoniczne” 37(1990) 1, s. 5-17; M. Parchem, Zmartwychwstanie, odpłata po śmierci i życie wieczne w literaturze międzytestamentalnej, ,Verbum Vitae” 8(2009) 15, s. 99-142.

${ }^{6}$ Zob. F. Zeilinger, Wiara w zmartwychwstanie w Biblii, tłum. G. Rawski, Kraków 2011.

${ }^{7}$ Katechizm Kościoła katolickiego [dalej KKK], 1022.

${ }^{8}$ Zob. J. Ratzinger, Eschatologia - śmierć $i$ życie wieczne, tłum. M. Węcławski, Warszawa 1986, s. 239.
} 
pośrednie. Może to prowadzić do wniosku, że dogmat ten ma słaby fundament biblijny ${ }^{9}$, a w konsekwencji - powodować marginalizację tej prawdy wiary ${ }^{10}$.

Celem niniejszego artykułu jest ukazanie biblijnych podstaw nauki Kościoła o czyśćcu. Nie jest to zadanie łatwe, ponieważ autorzy natchnieni są niezwykle powściagliwi w tej kwestii (w Biblii nie pada słowo „czyściec” ani też nie ma jego opisu), a ponadto trzeba zastosować specjalną hermeneutykę, jako że w żadnej z perykop nie ma bezpośredniego pouczenia o czyśćcu.

Najważniejsze teksty dotyczące czyśćca to: 2 Mch 12,38-45, 1 Kor 3,10-15 oraz Mt 12,31-32.

\section{Modlitwy i ofiary za zmarlych (2 Mch 12,38-45)}

Temat oczyszczenia po śmierci sięga swymi korzeniami najmłodszych ksiąg Starego Testamentu i tzw. judaizmu międzytestamentalnego. W ten etap objawienia wpisuje się opowiadanie przekazane w Drugiej Księdze Machabejskiej. Kiedy po zwycięskiej bitwie stoczonej z wojskami Seleucydów Izraelici pod wodzą Judy Machabeusza zaczęli przygotowywać do pochówku swoich zabitych, ujawniła się przyczyna, dla której utracili oni życie: każdy z nich miał przy sobie cenne rzeczy poświęcone bożkom pogańskim, takie, których posiadanie i noszenie ze sobą było wyraźnie zabronione przez Prawo Mojżeszowe ${ }^{11}$.

Dla wszystkich więc stało się jasne, że to oni i z tej właśnie przyczyny zginęli. Wszyscy zaś wychwalali Pana, sprawiedliwego Sędziego, który rzeczy ukryte czyni jawnymi, a potem oddali się modlitwie (iketeia) i błagali, aby popełniony grzech (amartēma) został całkowicie wymazany (teleiōs exaleiphthēnai). Mężny Juda [...] uczyniwszy składkę pomiędzy ludźmi, posłał do Jerozolimy około dwu tysięcy srebrnych drachm, aby złożono ofiarę (thysia) za grzech. Bardzo pięknie i szlachetnie uczynił, myślał bowiem o zmartwychwstaniu. Gdyby bowiem nie był przekonany, że ci zabici zmartwychwstana, to modlitwa (euchomai) za zmarłych byłaby czymś zbędnym i niedorzecznym, lecz jeśli uważał, że dla tych, którzy pobożnie zasnęli, jest przygotowana najwspanialsza nagroda - była to myśl święta i pobożna. Dlatego właśnie sprawił, że złożono ofiarę przebłagalną (exilasmos) za zabitych, aby zostali uwolnieni od grzechu (tes hamartias apolythēnai; 2 Mch 12,40-45).

Juda Machabeusz uznał, że ocaleni powinni się wstawić u Boga za umarłymi w grzechu bałwochwalstwa obrońcami ojczyzny, aby ci mogli uzyskać Jego przebaczenie. Zaproponował więc podwójną formę pomocy:

${ }^{9}$ Zob. W. Granat, Dogmatyka katolicka. Synteza, Lublin 1967, s. 504.

${ }^{10}$ Spośród 2865 paragrafów KKK tylko trzy są poświęcone czyśćcowi.

${ }^{11}$ Zob. F. Gryglewicz, Księgi Machabejskie. Wstęp, przekład z oryginatu, komentarz, Poznań 1961, s. 342-343. 
- modlitwę (iketeia, euchomai);

- ofiarę przebłagalną w Jerozolimie (thysia, exilasmos).

W tej propozycji wyrażone jest przekonanie, że oddziaływanie modlitw i ofiar przebłagalnych wykracza daleko poza granice doczesnej egzystencji człowieka i może mu skutecznie pomagać nawet po śmierci. Chodzi o pośmiertne „uwolnienie od grzechu” (tes hamartias apolythēnai), a nawet o „całkowite wymazanie grzechu" (amartēman teleiōs exaleiphthēnai). To drugie wyrażenie oznacza dosłownie tak doskonałe i całkowite wymazanie błędnego słowa napisanego na papirusie lub pergaminie, że nie pozostaje po nim żaden ślad (por. Iz 43,25; Kol 2,14).

Juda Machabeusz jest przekonany, że modlitwą i ofiarą można zmienić los człowieka po śmierci i wybłagać dla niego przebaczenie grzechów. Nie może tu jednak chodzić ani o niebo, ani też o piekło, ale o jeszcze inny stan, taki, w którym zmiany są możliwe. Autor natchniony wskazuje więc, choć nie wprost, na istnienie czyśćca.

Jest jeszcze kilka innych miejsc w Piśmie Świętym poświadczających, że ludzie żyjący mogą wpływać na los zmarłych. Przykładem może być zachęta z Księgi Syracha:

Miej dar łaskawy dla każdego, kto żyje,

a nawet umarłemu nie odmawiaj łaski”" (chesed; Syr 7,33).

Cechą tego wersetu jest paralelizm: pierwszy stych odnosi się do losu człowieka żyjącego, a drugi - do doli umarłego. Żywemu należy udzielić „,daru łaskawego", czyli realnej, wymiernej pomocy. Podobnie umarłemu należy okazać „łaskę” (chesed). Musi to być - przez analogię - realna pomoc. Jest nią godny pochówek, rzecz fundamentalna w mentalności i kulturze izraelskiej. Wydaje się jednak, że należy pójść jeszcze dalej i rozumieć pomoc dla zmarłego tak, jak ją pojmował Juda Machabeusz: modlitwą i ofiarą można realnie pomóc zmarłemu, wpływając na dalszy jego los. Tekst Syracha wskazuje więc pośrednio na istnienie czyśćca.

Również dwa teksty Pawłowe potwierdzają możliwość wstawiennictwa żyjących za zmarłymi: 1 Kor 15,29 i 2 Tm 1,16-18. Pierwszy z nich dotyczy bardzo zagadkowej kwestii - chrztu za zmarlych:

Bo inaczej czegoż dokonają ci, co przyjmują chrzest za zmarłych (hoi baptizomenoi hyper tō nekrōn)? Jeżeli umarli w ogóle nie zmartwychwstają, to czemuż za nich chrzest przyjmują? (1 Kor 15,29).

Werset ten jest częścią dłuższego pouczenia Pawła na temat zmartwychwstania i jego konsekwencji. Apostoł stawia Koryntianom, nie bez ironii, dwa pytania retoryczne, które można by oddać następująco: „Jakkolwiek Koryntianie nie wierzą w zmartwychwstanie, to jednak nie są konsekwentni, ponieważ przyjmują za zmarłych chrzest". 
Greków, przywykłych do platońskiego sposobu myślenia ${ }^{12}$, oburzała myśl o możliwości zmartwychwstania człowieka. Odrzucając je, praktykowali jednak pewien zwyczaj tak, jakby zmartwychwstanie miało nastapić - przyjmowali mianowicie „chrzest za zmarłych”. Paweł czyni tym wyrażeniem aluzję do jakiejś praktyki religijnej w Koryncie, której dotąd nie udało się jednoznacznie rozszyfrować ${ }^{13}$.

Dla niniejszego opracowania nie trzeba rozstrzygać, czym była ta praktyka. Wystarczy stwierdzić jedno: stawiając Koryntianom dwa pytania retoryczne, Paweł potwierdza ogólną zasadę możliwości niesienia pomocy zmarłym przez żywych. Taka pomoc jest możliwa jedynie wówczas, kiedy przyjmie się, że obok dwóch stanów definitywnych po śmierci (nieba, piekła) istnieje jeszcze inny, w którym zmiany są możliwe. Ten stan nazywa się czyśćcem ${ }^{14}$.

$\mathrm{Na}$ jeszcze inny sposób pomocy ludziom zmarłym przez żywych wskazuje następująca perykopa z listu pasterskiego Pawła do Tymoteusza:

${ }^{16}$ Niechże Pan użyczy miłosierdzia domowi (oikos) Onezyfora za to, że często mnie krzepił i łańcucha mego się nie zawstydził, ${ }^{17}$ lecz skoro się znalazł w Rzymie, gorliwie mnie poszukał i odnalazł. ${ }^{18}$ Niechaj mu da Pan (Kyrios) w owym dniu znaleźć miłosierdzie u Pana (Kyrios)! A jak wiele mi wyświadczył w Efezie, ty wiesz lepiej (2 Tm 1,16-18).

Paweł pouczał Tymoteusza, aby trzymał się zdrowych zasad (2 Tm 1,13) i strzegł Ewangelii $(2 \mathrm{Tm}$ 1,14). Podał mu też negatywne przykłady tych, którzy zawiedli $(2 \mathrm{Tm} 1,15)$. A teraz, w omawianym fragmencie, wskazuje mu pozytywny przykład chrześcijanina. Jest nim Onezyfor, który często krzepił Pawła i nie wstydził się jego uwięzienia.

O Onezyforze wiadomo niewiele ${ }^{15}$. Jest wspomniany jedynie w $2 \mathrm{Tm}$ 1,16-18 oraz $2 \mathrm{Tm} 4,19$, i to jeszcze nie wprost. Pochodził prawdopodobnie z Efezu albo okolicy, gdzie podlegał pasterskiej trosce Tymoteusza. Podróżował również do Rzymu, gdzie nie bez trudu odnalazł Pawła i wspierał go swoją przyjaźnią,

${ }^{12}$ Ciało w dialogu Platona Fedon jest nazwane więzieniem, a śmierć - wyjściem duszy z więzienia. Stąd zmartwychwstanie ciała według koncepcji Platona jest czymś niedorzecznym.

${ }^{13}$ Istnieje około 40 hipotez wyjaśniających „chrzest za zmarłych”. Zob. E. Dąbrowski, Listy do Koryntian. Wstęp, przekład z oryginatu, komentarz, Poznań 1965, s. 279.

${ }^{14}$ Zob. A. Jankowski, Eschatologia biblijna Nowego Testamentu, Kraków 1987, s. 225.

15 Acta Sanctorum wspominają męczennika imieniem Onezyfor, który zginął w Parium w Myzji między rokiem 102 a 114 po Chr. Zob. W. Ramsay, Notes on the „Acta” of Martyrs, „The Expository Times" 9(1898) s. 495-497. Również apokryf Dzieje Pawta i Tekli (2,353-354) z II w. po Chr. wspomina Onezyfora, jego żonę Lektrę oraz dzieci Simmiasza i Zenona, którzy towarzyszyli Pawłowi w drodze z Antiochii do Ikonium. Zob. W. Mounce, Pastoral Epistles, Dallas 2002 (Word Biblical Commentary 46), s. 491. Nie wiadomo jednak, czy w tych tekstach chodzi o Onezyfora z 2 Tm 1,16-18. 
i utrzymywał. Onezyfor był dla Pawła tak wielkim wzorem dobrego chrześcijanina i człowieka, że wspominał go, pisząc do Tymoteusza.

Wydaje się, że w momencie redakcji Listu Onezyfor już nie żył. Wskazywać na to mogą następujące fakty ${ }^{16}$ :

- Werset 16 odnosi się wyraźnie do teraźniejszości. Paweł nie wspomina jednak samego Onezyfora, a jedynie jego „dom” (oikos). Może to sugerować, że Onezyfor nie należał już w tym momencie do tego „domu”, zaś prośba apostoła o „miłosierdzie Pana” dla „,domu” była w istocie błaganiem, aby ta społeczność zdołała podołać wszystkim wyzwaniom mimo nieobecności swej głowy.

- Prośba zawarta w wersecie 18 odnosi się nie do domu Onezyfora (jak w wersecie 16), ale do niego samego. Widać wyraźne przesunięcie akcentu ku przyszłemu dniowi sądu. Może to świadczyć, że Onezyfor umarł i staje na sądzie Bożym.

- Czas przeszły użyty w tej perykopie sugeruje, iż Onezyfor nie żyje i że każde wspominane tu wydarzenie należy już - z perspektywy Pawła - do przeszłości.

- Jeszcze jedna wskazówka mogąca świadczyć o śmierci Onezyfora znajduje się w końcowym pozdrowieniu Listu. Paweł określa tam osoby po imieniu, a jedynie w przypadku Onezyfora robi wyjątek i pozdrawia jego „dom”. Z uwagi na bliską więź łączącą Pawła z Onezyforem może wydawać się dziwne, że apostoł - jeśli jego przyjaciel wówczas żył - nie pozdrowił go imiennie.

- Można odnieść wrażenie, że werset $18 \mathrm{~b}$ naturalnie łączy się z wersetem 17, a werset 18a przerywa logikę tekstu, co wskazuje, iż z Onezyforem prawdopodobnie coś się stało.

Z przytoczonych argumentów można przyjąć jako prawdopodobny wniosek, że Onezyfor w momencie pisania Listu już nie żył. Jeśli tak, wówczas werset 18a: „Niechaj mu da Pan (Kyrios) w owym dniu znaleźć miłosierdzie u Pana (Kyrios)!" zawiera modlitwę za zmarłego (jedyną w Nowym Testamencie).

Komentatorzy są zgodni, że użyte dwukrotnie w tej modlitwie słowo Kyrios ma dwa znaczenia: pierwsze, z rodzajnikiem, oznacza Chrystusa (por. Rz 2,6; 3,6), a drugie, bez rodzajnika, oznacza Boga Ojca ${ }^{17}$. Paweł prosi więc Boga Ojca o „miłosierdzie” dla Onezyfora „w dniu [jego sądu]”, a czyni to za pośrednictwem Chrystusa ${ }^{18}$. Chrystus bowiem, zmartwychwstając, zapanował także nad

\footnotetext{
${ }^{16}$ Zob. W. Mounce, Pastoral Epistles, dz. cyt., s. 491-492.

${ }^{17}$ W Septuagincie Kyrios bez rodzajnika jest imieniem Boga. Zob. G. Quell, Kyrios, w: Theological dictionary of the New Testament, red. G. Kittel, G. Friedrich, Grand Rapids 1982, s. 1058-1059 .

${ }^{18}$ Jezus często zapewniał o swoim wstawiennictwie u Ojca, zwłaszcza w chwili sądu (Mt 5,7; $10,32 ; 14,16 ; 16,26)$ i o swoim sądzie miłosiernym (Mt 25,36). Zob. A. Jankowski, Eschatologia biblijna..., dz. cyt., s. 225 .
} 
światem umarłych (Rz 14,9; 1 P 3,19) i dlatego aż do dnia sądu ostatecznego może się wstawiać za każdym zmarłym u Ojca ${ }^{19}$.

Modlitwa Pawłowa nie mówi wprost o oczyszczeniu duszy po śmierci. Samo jednak wstawiennictwo apostoła oraz odwołanie się do miłosierdzia Bożego świadczą, że człowiek stając po śmierci przed Bogiem, potrzebuje dalszego oczyszczenia. To wskazuje na możliwość zmiany losu człowieka po śmierci za sprawą modlitwy żyjących i poświadcza taki stan pośmiertny, który nie jest ani niebem, ani piekłem.

Przy okazji warto wspomnieć, że teologowie rozważają różne możliwości oddziaływania modlitw i ofiar na dusze czyśćcowe: albo „skracają" one ich pobyt w czyśćcu, albo umacniają je w znoszeniu mąk czyśćcowych, albo wreszcie łagodzą dotkliwość czyśćcowych kar. Z całą pewnością wstawiennictwo oddziałuje też na żyjących, ponieważ daje im możliwość świadczenia miłości umarłym ${ }^{20}$.

\section{Oczyszczenie przez ogień (1 Kor 3,10-15)}

W Katechizmie Kościoła katolickiego znajduje się bardzo ogólnikowa wzmianka o sposobie oczyszczenia duszy po śmierci: „Tradycja Kościoła, opierając się na niektórych tekstach Pisma Świętego, mówi o ogniu oczyszczającym" (KKK 1031). Jedna z perykop biblijnych odnoszących się do ognia oczyszczającego znajduje się w Pierwszym Liście do Koryntian. Paweł nawiązuje do rozłamów w Kościele korynckim i przypomina adresatom, że jako apostoł położył u nich mocny i niezawodny fundament, na którym każdy z nich ma budować swoje życie.

${ }^{11}$ Fundamentu bowiem nikt nie może położyć innego, jak ten, który jest położony, a którym jest Jezus Chrystus. ${ }^{12}$ I tak jak ktoś na tym fundamencie buduje: ze złota (chrysos), ze srebra (argyros), z drogich kamieni (lithoi timioi), z drewna (xylon), z trawy (chortos) lub ze słomy (kalamē), ${ }^{13}$ tak też jawne się stanie dzieło każdego: odsłoni je dzień (hēmera) [Pański]; okaże się bowiem w ogniu (en pyri), który je wypróbuje, jakie jest. ${ }^{14}$ Ten, którego budowla wzniesiona na fundamencie przetrwa, otrzyma zapłatę; ${ }^{15}$ ten zaś, którego dzieło spłonie, poniesie szkodę: sam wprawdzie ocaleje, lecz tak jakby przez ogień (dia pyros; 1 Kor 3,11-15).

Zadaniem wszystkich ludzi jest właściwe kształtowanie swojego życia. Paweł poucza o tym, posługując się alegorią budowania domu. Jego fundamentem jest Jezus Chrystus, a kształt i jakość kolejnych nadbudowywanych części są pozostawione do decyzji człowieka. Apostoł wymienia sześć materiałów budow-

19 Zob. tamże, s. 226.

${ }^{20}$ Zob. G. Anderson, Is purgatory biblical?, „First Things” 11 (2011), s. 44. 
lanych, z których korzysta budujący, przy czym trzy z nich (złoto, srebro, drogie kamienie) są szlachetne, trwałe i ognioodporne, a trzy (drewno, trawa, słoma) są mniej cenne, mało trwałe i łatwopalne. Materiały są obrazem duchowego budulca, jakim posługują się poszczególni ludzie, kształtując swoje życie.

Jakkolwiek budowla wznoszona z kiepskiej jakości materiału nie wymaga wielkich nakładów i może przez jakiś czas spełniać swoją funkcję, to jednak nie przejdzie rygorystycznej próby ostatecznej. Prawdę o jakości budowania odsłoni „dzień" (hèmera), w sensie hēmera Kyriou, czyli paruzja Chrystusa. Wtedy to „W ogniu" (en pyri) sądu Bożego ocaleją ci, którzy kształtowali swe życie, opierając się na materiale szlachetnym i odpornym na ogień. Natomiast pozostali, których życie spłonie, poniosą klęskę, ale ostatecznie i oni będą mieli szansę ocaleć, „lecz tak jakby przez ogień” (dia pyros). Czy ocalenie ,jakby przez ogień” oznacza czyściec?

Warto zauważyć, że w tej perykopie dwukrotnie występuje słowo „ogień” (pyr) i za każdym razem ma inne znaczenie:

- W wersecie 13 pyr jest atrybutem „Dnia Pańskiego”. Jest to ogień rozświetlający tajemnice dotąd ukryte, palący oraz poddający próbie wartość i trwałość wszystkiego, czego dotknie ${ }^{21}$. Taki właśnie ogień, który w „Dniu Pańskim” rozdzieli to, co dobre, od tego, co złe, i zniszczy to, co nietrwałe i przygodne, zapowiadali prorocy w Starym Testamencie (np. Iz 66,15; Ml 3,1-5.19-21)22 i autorzy natchnieni w Nowym (2 Tes 1,8).

Ten rodzaj ognia wpisuje się w biblijną teologię „oczyszczania w ogniu” albo „próbowania w ogniu” (np. Łk 3,17; 1 P 1,7; Ap 3,18)23.

- W wersecie 15 pyr ma zupełnie inny charakter: nie niesie zniszczenia, ale przeciwnie, ocalenie.

Czy tekst św. Pawła jest dowodem formalnym na istnienie czyśćca? Z cała pewnością explicite nie. Niemniej jednak omawiana perykopa rzuca podwaliny pod prawdę o czyśćcu i stanowi podstawę do dalszych dedukcji teologicznych. Apostoł uczy bowiem o dwóch odmiennych drogach prowadzących do zbawienia. Jedna dotyczy ludzi, którzy kształtowali swoje życie na fundamencie Chrystusa i których budowla przetrwała ostateczną próbę; ci zaraz otrzymują „,zapłatę". Druga dotyczy tych, którym za życia zabrakło doskonałości i szlachetności. Oni również mają szansę ocaleć dla nieba, ale dopiero po przejściu dia pyros (przez ogień).

Refleksja teologiczna nad znaczeniem przechodzenia ,przez ogień" znajdzie się w dalszej części niniejszego studium.

${ }^{21}$ Zob. E. Dąbrowski, dz. cyt., s. 168.

${ }^{22}$ Zob. A. Jankowski, Eschatologia biblijna..., dz. cyt., s. 229-230.

${ }^{23}$ Być może Paweł miał na myśli wielki pożar Koryntu w roku 146 przed Chr. wzniecony w ramach odwetu za opór miasta wobec Rzymu. 
Z tekstem 1 Kor 3,10-15 o ogniu oczyszczającym wiąże się pouczenie Księgi Apokalipsy: „Nic nieczystego (pan koinon) do [Miasta] nie wejdzie” (Ap 21,27).

„Miasto” w Ap 21-22 jest „środowiskiem życiowym” Boga, metaforą nieba i zbawienia, miejscem świętym i czystym. Nie przystaje do niego najmniejsza nieczystość.

W Starym Testamencie nieczystość miała zwykle charakter nieczystości rytualnej (por. Kpł 10,1; Iz 35,8; 52,1), natomiast w Nowym Testamencie nabrała ona charakteru moralnego (Mt 15,11; 18,20; Mk 7,2.5.15.18.20.23; Hbr 9,13; Dz $10,14.15 .28 ; 11,8.9 ; 21,28)$. Autor natchniony wyraził ją terminem koinos; w takim sensie występuje ona $\mathrm{w}$ Apokalipsie tylko jeden raz. Bliskim synonimem koinos jest przymiotnik akathartos (Ap 16,13; 17,4; 18,2).

Aniołowie, którzy symbolicznie strzegą bram „Miasta” (Ap 21,12), mają za zadanie zatrzymać każdego, kto jest „nieczysty”, czyli skalany jakąkolwiek winą, i zakazać mu wstępu. Pośrednio może to wskazywać na czyściec, czyli stan oczyszczenia, gdzie „nieczysty” staje się czysty i gotowy do wejścia do „Miasta, Nowego Jeruzalem", eschatycznej fazy królestwa Boga ${ }^{24}$.

\section{Odpuszczenie grzechów po śmierci}

Trzeci tekst biblijny odnoszący się wyraźniej do prawdy o czyśćcu znajduje się w Ewangelii według św. Mateusza, w perykopie o grzechu przeciw Duchowi Świętemu:

${ }^{31}$ Każdy grzech i bluźnierstwo będą odpuszczone ludziom, ale bluźnierstwo przeciwko Duchowi nie będzie odpuszczone. ${ }^{32}$ Jeśli ktoś powie słowo przeciw Synowi Człowieczemu, będzie mu odpuszczone, lecz jeśli powie przeciw Duchowi Świętemu, nie będzie mu odpuszczone ani w tym wieku, ani w przyszłym (oute en toutō tō aiōni oute en tō mellonti; Mt 12,31-32).

Perykopa o grzechu przeciw Duchowi Świętemu jest krótka i składa się z dwóch wersetów. Oba mają podobną treść i oba składają się z dwóch członów, które tworzą paralelizm oparty na czasowniku aphiēmi ('przebaczać') ${ }^{25}$. Strukturę perykopy można przedstawić następująco ${ }^{26}$ :

w. 31: (a) przebaczenie wszystkich grzechów i bluźnierstw;

(b) brak przebaczenia bluźnierstwa przeciw Duchowi Świętemu.

w. 32: (a) przebaczenie dla tych, którzy mówią przeciw Synowi Człowieczemu;

(b) brak przebaczenia dla tych, którzy mówią przeciw Duchowi Świętemu.

\footnotetext{
${ }^{24}$ Zob. D. Aune, Revelation 17-22, Word Biblical Commentary 52c, Dallas 2002, s. 1174.

${ }^{25}$ Występuje ono cztery razy w niezmiennej formie aphethēsetai (,zostanie odpuszczone”).

${ }^{26}$ Zob. D. Hagner, Matthew 1-13, Word Biblical Commentary 33a, Dallas 2002, s. 347.
} 
$\mathrm{W}$ analizie perykopy pomijamy zupełnie kwestię, czym jest w istocie grzech przeciwko Synowi Człowieczemu oraz Duchowi Świętemu, natomiast skoncentrujemy się na niepozornej wskazówce dotyczącej możliwości odpuszczenia tych grzechów. Otóż Mateusz podaje ogólnie, że grzech „,przeciw Synowi Człowieczemu” może zostać odpuszczony, natomiast grzech ,przeciw Duchowi Świętemu" - nie. I dodaje podwójną okoliczność: „,ani w tym wieku $(a i \bar{o} n)^{27}$, ani w przyszłym", czyli ani za życia człowieka, ani po jego śmierci ${ }^{28}$.

Skoro nie można otrzymać odpuszczenia grzechu przeciw Duchowi Świętemu ani w doczesności, ani w przyszłym świecie, można zaś otrzymać przebaczenie innych grzechów i bluźnierstw, oznacza to, że istnieje możliwość odpuszczenia niektórych win już po śmierci człowieka. Taka perspektywa nie może się jednak odnosić ani do zbawionych w niebie, ani do potępionych w piekle. Pouczenie Chrystusa o uwolnieniu człowieka od grzechów innych niż przeciw Duchowi Świętemu w przyszłym życiu można odnieść do prawdy o czyśćcu.

Podobny sens, choć w interesującej nas kwestii nieco mniej wyrazisty, zawiera paralelny tekst u Marka:

${ }^{28}$ Wszystkie grzechy i bluźnierstwa, których by się ludzie dopuścili, będą im odpuszczone. ${ }^{29}$ Kto by jednak zbluźnił przeciw Duchowi Świętemu, nigdy (eis ton aiōna) nie otrzyma odpuszczenia, lecz winien jest grzechu wiecznego (Mk 3,28-29).

U Marka wyrażenie eis ton aiōna może oznaczać 'doczesność' (por. np. Mk 11,14), jednak w analizowanym wersecie 29 oznacza zarówno 'doczesność', jak i 'erę, która ma nadejść' 29 . Eis ton aiōna trzeba rozumieć jako 'nigdy'30.

Przebaczenia grzechu przeciw Duchowi Świętemu nie można otrzymać nigdy, inne zaś grzechy mogą być odpuszczone pod pewnymi warunkami i za życia człowieka, i już po jego śmierci. Kolejny raz powraca myśl o czyśćcu.

Trzy omówione wyżej perykopy (2 Mch 12,38-45, 1 Kor 3,10-15 i Mt 12,31-32) wskazują na możliwość zmiany losu człowieka już po jego śmierci. Perykopa o grzechu przeciw Duchowi Świętemu poświadcza możliwość dalszego przebaczania win po jego śmierci, tekst Pawłowy wskazuje na tajemniczy ogień oczyszczający człowieka w przyszłym świecie, a fragment z Księgi Machabejskiej uczy, że śmierć żołnierzy-bałwochwalców Judy Machabeusza, choć sama w sobie była

${ }^{27}$ Aiōn oznacza albo długotrwały okres, który już przeminą, albo długą erę, która dopiero nadejdzie, albo aktualne i niezmienne długie trwanie.

${ }^{28}$ Język obejmujący dwie ery (teraźniejszość i nadchodzącą wieczność) był typowy dla judaizmu, używał go również Mateusz (np. Mt 13,39.40; 24,3). Zob. H. Strack, P. Billerbeck, Kommentar zum Neuen Testament, vol. 4.2, München 1928, s. 799-976.

${ }^{29}$ Zob. R. Guelich, Mark 1-8:26, Word Biblical Commentary 34a, Dallas 2002, s. 179.

${ }^{30}$ Zob. V. Taylor, The Gospel according to St. Mark, London-New York $1966^{2}$, s. 243. 
dla nich karą, była zadośćuczynieniem niewystarczającym. Dla zmarłych skuteczne jest wstawiennictwo żywych (modlitwa, ofiara) ${ }^{31}$.

Przesłanie tych tekstów wskazuje na odmienny od nieba i od piekła stan po śmierci człowieka - nazywany umownie czyśćcem.

W kolejnej części opracowania wskażemy na kilka tekstów w Piśmie Świętym, które można interpretować w kluczu biblijnych metafor czyśćca.

\section{Metafory czyśćca: chłosta (Lk 12,47-48)}

W 12. rozdziale Ewangelii Łukasz przekazuje zachęty do czujności i do wierności Chrystusowi ${ }^{32}$. Używa przy tym obrazów przepasanych bioder i zapalonych pochodni, przytacza przypowieści o sługach oczekujących powrotu pana i o gospodarzu, który nie zna godziny nadejścia złodzieja. Na pytanie Piotra („Czy do nas mówisz tę przypowieść, czy też do wszystkich?"; Łk 12,41) Jezus odpowiada kolejną przypowieścią o nagrodzie dla wiernego sługi oraz o karze dla sługi, który sprzeniewierzył się swym obowiązkom. Całość pouczenia kończy jeszcze jedna podwójna przypowieść Jezusa - o zależności kary, która dosięga sługę, od znajomości woli pana ${ }^{33}$. Przypowieść ta będzie przedmiotem obecnej refleksji:

Sługa, który zna wolę swego pana, a nic nie przygotował i nie uczynił zgodnie z jego wolą, otrzyma wielką chłostę (darēsetai pollas). Ten zaś, który nie zna jego woli i uczynił coś godnego kary, otrzyma małą chłostę (darēsetai oligas; Łk 12,47-48).

Przypowieść zbudowana jest na zasadzie paralelizmu antytetycznego i być może przekazuje ipssisima verba Iesu ${ }^{34}$.

Panem w przypowieści jest Bóg, a sługami albo przywódcy Izraela i lud, który nie zna Prawa, albo Żydzi i poganie, albo też uczniowie Chrystusa i poganie. Kara $\mathrm{w}$ przypowieści jest zróżnicowana $\mathrm{w}$ zależności od spełnienia woli Bożej. Ponieważ kontekst przypowieści jest eschatyczny, również i kara musi mieć charakter eschatyczny. Jej wymierzenie zakłada wcześniejszy sąd, który w perykopie nie jest wspomniany. W przypowieści chodzi więc o wolę Bożą, o Boży sąd i o Bożą karę ${ }^{35}$.

Kara w przypowieści wyrażona jest obrazem chłosty: sługa bardziej winny darēsetai pollas ('będzie chłostany wieloma [razami]'), drugi, mniej winny darēsetai oligas ('będzie chłostany nielicznymi [razami]').

${ }^{31}$ Zob. A. Jankowski, Eschatologia biblijna ..., dz. cyt., s. 215-216.

${ }^{32}$ Zob. F. Gryglewicz, Ewangelia wedlug św. Lukasza. Wstęp, przekład z oryginalu, komentarz, Poznań 1974, s. 241.

${ }^{33}$ Zob. J. Nolland, Luke 9:21-18:34, Word Biblical Commentary 35b, Dallas 2002, s. 704.

${ }^{34}$ Zob. J. Ernst, Das Evangelium nach Lukas, Regensburg 1977, s. 411.

${ }^{35}$ Zob. S. Wronka, Eschatologiczna kara w $Ł k$ 12,47-48a, ,Zeszyty Naukowe Stowarzyszenia Biblistów Polskich” 2(2005), s. 266. 
Czy chłosta jako obraz eschatycznej kary oznaczać może tu piekło? Wydaje się, że raczej nie. O karze potępienia mówiła wcześniejsza przypowieść o słudze, który sprzeniewierzył się swoim obowiązkom (Łk 12,45-46): pan „każe go ćwiartować (dichotomeō) i z niewiernymi wyznaczy mu miejsce" (Łk 12,46). Czasownik dichotomeō oznacza dosłownie 'rozciąć na dwie części', czyli de facto zadać śmierć $^{36}$. Na odrzucenie sługi wskazuje nadto zwrot: „z niewiernymi wyznaczy mu miejsce": podzieli on los tych, którzy byli niewierni (apistoi).

Można powiedzieć, że kara w przypowieści Łk 12,45-46 ma wyraźnie charakter definitywny i ,zamknięty”. Natomiast chłosta jako kara (Łk 12,47-48) ma charakter „otwarty”, ponieważ nie kończy się śmiercią ukaranego ${ }^{37}$. Ma ona charakter pedagogiczny i jest formą zadośćuczynienia za potępione $z^{30}{ }^{38}$.

Chłosta jako kara doczesna nie zamyka drogi do wolności i do życia. Ma ona charakter tymczasowy i pokutny. Ten rys można przenieść na stan po śmierci. Eschatyczna chłosta jest doświadczeniem innym niż wieczne potępienie. Nie trwa bez końca, lecz ma charakter przejściowy i wychowawczy. Nie odbiera nadziei wiecznego zbawienia, ale prowadzi do bezpośredniego oglądania Boga ${ }^{39}$. W tym sensie chłosta z Łk 12,7-48, zróżnicowana na większą i mniejszą (czyli w pewnym sensie stopniowana), może być metaforą czyśćca, biblijnym obrazem stanu po śmierci, który ma charakter kary, jednak nie wiecznej. „Być może Zbawiciel wybrał porównanie, które nie zawiera kary śmierci, aby podsunąć myśl, że na sądzie Bożym jest kara, która nie jest wieczną zatratą"40.

\section{Metafory czyśćca: więzienie za długi (Mt 5,25-26; 18,34)}

Kolejną biblijną metaforę czyśćca można odnaleźć w Kazaniu na górze, we fragmencie poświęconym udoskonaleniu przykazania „Nie zabijaj” (Mt 5,21-26). Perykopa ta składa się z trzech części: właściwej antytezy, dodatkowego objaśnienia oraz zachęty do pojednania zilustrowanej dwoma przykładami, pojednania z „bratem” oraz z „przeciwnikiem”. Oba przykłady naświetlają radykalizm wymogu Chrystusa wykraczający poza tradycyjne rozumienie Prawa.

Przedmiotem niniejszego studium jest fragment o pojednaniu z przeciwnikiem:

\footnotetext{
${ }^{36}$ W Ap 21,8 „śmierć druga” oznacza wieczne potępienie.

${ }^{37}$ Przykładem może być uwolnienie po ubiczowaniu apostołów (Dz 5,40), Pawła (Dz 16,35), a nawet próba uwolnienia Jezusa przez Piłata („Każę Go więc wychłostać i uwolnię”; Łk 23,16$-22)$.

${ }^{38}$ Rózga jest w Biblii jednym z atrybutów dobrego wychowawcy (np. 2 Sm 7,14; Ps 89,33; Prz 13,24; 22,15; 23,13; Syr 33,1; 1 Kor 4,21).

${ }^{39}$ Zob. S. Wronka, Eschatologiczna kara w $Ł k$ 12,47-48a, dz. cyt., s. 287, 290.

${ }^{40}$ M.J. Lagrange, Evangile selon sait Luc, Paris 1948, s. 371.
} 
Pogódź się ze swoim przeciwnikiem (antidikos) szybko, dopóki jesteś z nim w drodze, by cię przeciwnik nie podał sędziemu (kritês), a sędzia dozorcy (hypērētes), i aby nie wtrącono cię do więzienia (phylakē). Zaprawdę, powiadam ci: nie wyjdziesz stamtąd, aż zwrócisz ostatni grosz (kodrantēs; Mt 5,25-26).

Perykopa ma formę krótkiej przypowieści o konieczności niezwłocznego pojednania się z przeciwnikiem, zanim jeszcze zapadnie wyrok skazujący ${ }^{41}$. Użyta terminologia jest wyraźnie sądownicza (sędzia, dozorca, więzienie). O jaki charakter sądu i wyroku może tutaj chodzić? W znalezieniu odpowiedzi na to pytanie może pomóc ta sama przypowieść w redakcji Łukaszowej (Łk 12,58-59), a dokładniej - jej kontekst. U Mateusza przypowieść o pojednaniu służy ilustracji pogłębionego spojrzenia na piąte przykazanie Dekalogu, natomiast u Łukasza pojawia się w kontekście jednoznacznie eschatycznym, wśród takich tematów jak przyznawanie się i nieprzyznawanie do Jezusa, nocne zawezwanie głupiego bogacza przed sąd, gotowość wiernych sług na powrót ich pana i brak gotowości niewiernego sługi, a także umiejętność rozpoznawania znaków czasu.

W takim kontekście przypowieść o wyroku dla człowieka niepojednanego z przeciwnikiem nabiera charakteru eschatycznego. Sędzią jest Bóg, a sąd ma charakter Bożego rozstrzygnięcia następującego po śmierci człowieka. Tematem przypowieści byłoby więc pouczenie, że każdy człowiek musi odpowiedzieć przed sądem Bożym, a w przypadku zaniedbań - trafia do eschatycznego więzienia, w którym będzie spłacał zaciagnięte długi ${ }^{42}$. Dopiero, kiedy wpłaci ostatni zaległy „grosz”43 (Mt 5,26) albo „pieniążek”"44 (Łk 12,59), będzie mógł więzienie opuścić.

Eschatyczne więzienie, które będzie można opuścić po spłaceniu wszystkich długów, czyli po wypłaceniu się Bogu z najmniejszych nawet popełnionych win (w judaizmie winy wobec Boga nazywano długami: opheilemmata; por. Mt 6,12), nie może więc oznaczać wiecznego potępienia, ale jedynie przejściową karę. Dlatego biblijne więzienie, do którego został wtrącony dłużnik, można rozumieć jako metaforę czyśćca i odczytywać perykopy Mt 5,25-26/Łk 12,58-59 jako pośmiertne oczyszczenie $\mathrm{z}$ win ${ }^{45}$.

${ }^{41}$ Zob. J. Homerski, Ewangelia według św. Mateusza. Wstęp, przekład z oryginału, komentarz, Poznań 1979, s. 135.

${ }^{42}$ Tło tej przypowieści wydaje się nieżydowskie, bo Żydzi nie mieli zwyczaju wtrącać do więzienia za długi. Zob. D. Hagner, Matthew 1-13, Word Biblical Commentary 33a, Dallas 2002, s. 117.

${ }^{43}$ Biblijny „grosz” to rzymski miedziany pieniążek zwany kodrantēs. Jest to grecka forma łacińskiego słowa quadrans, czyli 1/4 asa albo 1/64 denara.

${ }^{44}$ Biblijny ,pieniążek” to leptos, połowa quadransa, czyli 1/128 denara (zob. Mk 12,42). Mateusz podaje w przypowieści kwotę dwa razy większą niż Łukasz.

${ }^{45}$ Zob. A. Jankowski, Eschatologia biblijna..., dz. cyt., s. 221. 
Tę samą hermeneutykę można zastosować do podobnego tekstu Mateusza o niegodziwym słudze:

Pan jego wezwał go przed siebie i rzekł mu: Sługo niegodziwy! Darowałem ci cały ten dług, ponieważ mnie prosiłeś. Czyż więc i ty nie powinieneś był ulitować się nad swoim współsługą, jak ja ulitowałem się nad tobą? I uniesiony gniewem pan jego kazał wydać go katom (basanistēs), dopóki mu całego długu nie odda (opheilomenon). Podobnie uczyni wam Ojciec mój niebieski, jeżeli każdy z was nie przebaczy z serca swemu bratu (Mt 18,32-35).

Podobnie jak w poprzedniej przypowieści, mamy tu winowajcę, sędziego (pana) i więzienie z katami. Sędzia pełen gniewu wydaje wyrok: przekazuje winowajcę katom do więzienia i poleca trzymać go i męczyć tak długo, aż spłaci cały dług.

Żydzi nie mieli w zwyczaju torturować skazanych w więzieniu. Natomiast w więzieniach rzymskich osadzonych torturowano. Tortury wyraźnie wskazują tutaj na karę eschatyczną (por. ,płacz i zgrzytanie zębów”; Mt 24,51; 25,30; Łk 13,28).

Ponieważ więzień nie miał możliwości zdobycia pieniędzy na spłatę długu, z pomocą musieli mu pospieszyć krewni i przyjaciele, by go wykupić i ulżyć jego doli. Po zebraniu przez nich wymaganej kwoty mógł opuścić więzienie ${ }^{46}$.

Odczytując eschatyczne więzienie pełne tortur jako metaforę czyśćca, można dodatkowo wydobyć jeszcze jeden ważny element: wsparcie krewnych i znajomych dla biedaka, który nie ma możliwości zdobycia pieniędzy, można przenośnie interpretować jako wspomnianą wcześniej pomoc żyjących dla cierpiących w czyśćcu, zwłaszcza zaś jako ich modlitwy i ofiary.

\section{Metafory czyśćca: opuszczenie otchłani (Mt 12,4)}

Niektórzy komentatorzy upatrują metafory czyśćca również w historii Jonasza, który spędził „we wnętrznościach ryby trzy dni i trzy noce. Z wnętrzności ryby modlił się Jonasz do Pana, Boga swego [...] W utrapieniu moim wołałem do Pana, a On mi odpowiedział. Z głębokości Szeolu wzywałem pomocy, a Ty usłyszałeś jego głos [...] Gdy gasło we mnie życie, wspomniałem Pana, a modlitwa moja dotarła do Ciebie [...] I Pan nakazał rybie i wyrzuciła Jonasza na ląd” (Jon 2, 1-3.8.11).

Na historię Jonasza powołał się Jezus, gdy uczył o swym przyszłym zmartwychwstaniu:

Albowiem jak Jonasz był trzy dni i trzy noce we wnętrznościach wielkiej ryby, tak Syn Człowieczy będzie trzy dni i trzy noce w łonie ziemi (Mt 12,40).

${ }^{46}$ Zob. D. Hagner, Matthew 14-28, Word Biblical Commentary 33b, Dallas 2002, s. 540. 
W myśl biblijnego sensu typicznego Jonasz jest antytypem Chrystusa Zmartwychwstałego. Niemniej jednak można też spojrzeć na historię wyjścia Jonasza z wnętrzności ryby jako na metaforę czyśćca, który „wyrzuca” ludzi „na ląd”, czyli do nieba.

\section{Czyściec w przypowieści o Lazarzu i bogaczu (Lk 16,19-31)}

Przypowieść o Łazarzu i bogaczu, którą Łukasz umieścił w części poświęconej niebezpieczeństwu bogactw, jest zwykle objaśniana jako biblijny obraz eschatycznej rzeczywistości nieba i piekła. W. Chrostowski jako pierwszy proponuje interpretację tego tekstu w kluczu chrześcijańskiej nauki o czyśćcu ${ }^{47}$ i traktuje sytuację ukaranego bogacza nie jako nieodwracalne potępienie, ale jako przejściowe oczyszczanie w miejscu nazwanym otchłanią (hadēs). Za taką interpretacją wysuwa następujące argumenty:

- Bogacz w przypowieści nazywa Abrahama „ojcem”. Śmierć nie zabiła W nim świadomości przynależności do Izraela jako do narodu wybranego oraz fizycznego i duchowego pokrewieństwa z protoplastą Ludu Bożego.

- Abraham nazywa bogacza „synem”. Śmierć nie zniszczyła więzi bogacza z narodem; należy on nadal do rodziny, której ojcem jest Abraham.

- Bogacz usiłuje zabezpieczyć swoją rodzinę przed zgubnymi skutkami złego życia, a to oznacza, że sytuacja kary nie zabiła w nim wrażliwości i troski o swoich bliskich, a zatem - kierują nim nadal dobre pobudki.

Gdyby bogacz był potępiony w piekle, byłby całkowicie zły i dogłębnie zepsuty; nie mógłby myśleć kategoriami dobra ani go zamierzać. Tymczasem tak nie jest. W jego losie nadal są obecne więzi ze światem dobra. Bogacz nie może więc być w piekle. Jego dosięga kara czyśćca!

Taka interpretacja Łukaszowej przypowieści odsłania nieco tajemnice świata czyśćcowego:

- Czyściec jest rzeczywistością przepełnioną wielkim cierpieniem, którego źródłem jest ogień (,strasznie cierpię w tym płomieniu”; Łk 16,24).

- Czyściec jest stanem oddalenia od Boga, a jednocześnie ogromnej tęsknoty za Nim („między nami a wami zionie ogromna przepaść”; Łk 16,26). Wyrazem tego oddalenia jest nieobecność Boga w przypowieści.

- Dusze czyśćcowe nie mogą się kontaktować ze światem ziemskim. Nadto też nie wiedzą, że ponoszona przez nie kara ma charakter przejściowy.

- Kary czyśćcowe są ekspiacją za grzechy nieodpokutowane w ziemskim życiu.

Taka interpretacja przypowieści niesie wielkie pocieszenie. Sąd nad grzesznikiem po śmierci i wymierzenie kary za brak miłości w jego ziemskim życiu wyni-

${ }^{47}$ Zob. W. Chrostowski, Niebo, piekło i czyściec w perspektywie biblijnej, w: tenże, Trzecia Światynia w Jerozolimie i inne studia, Warszawa 2012, s. 624-632. 
kają ze sprawiedliwości Boga, ale nie oznaczają całkowitego odrzucenia. Ostatnim słowem wobec człowieka pokutującego w czyśćcu jest miłosierdzie Boże.

Autorzy biblijni są niezwykle powściągliwi w kwestii czyśćca. Niemniej na podstawie przedstawionego dotąd materiału można wnioskować, że idee nieba i piekła nie wyczerpują biblijnych pouczeń o losie człowieka po śmierci. Z tekstów Pisma Świętego wynika, że jeszcze na drugim świecie można dostapić odpuszczenia grzechów i oczyszczenia oraz że ludzie żyjący mogą zmienić los zmarłego. W Biblii można też znaleźć metafory tego dodatkowego stanu, który Kościół nazywa czyśćcem.

Kolejnym etapem naszego studium będzie prezentacja nauki Kościoła o czyśćcu oraz refleksja teologiczna.

\section{Nauka Kościoła o czyśćcu}

Jakkolwiek Kościół sformułował oficjalnie doktrynę o czyśćcu dopiero w wiekach XIII, XV i XVI, to jednak wiara w ów przejściowy stan dusz, które potrzebują oczyszczenia do pełnego zjednoczenia z Bogiem, istniała w Kościele od samego początku ${ }^{48}$. Jej wyrazem był zwyczaj modlitw za zmarłych, które swymi korzeniami sięgały omówionego wcześniej tekstu z Drugiej Księgi Machabejskiej i żydowskich praktyk modlitewnych. Chrześcijanie od samego początku modlili się za zmarłych, a jednocześnie byli głęboko przekonani, że ani zbawieni w niebie, ani też potępieni w piekle modlitwy nie potrzebują. Wierzyli natomiast, że niektórym zmarłym modlitwa bardzo pomaga. Nie nazywając czyśćca „czyśćcem" - wierzyli w niego. Innym dowodem wiary w czyściec, sięgającej starożytności, są liczne zachowane napisy nagrobne w starochrześcijańskich katakumbach $^{49}$.

Wczesna wiara w czyściec miała też swoje drugie źródło. Wierni rozumieli, że samo stanie się chrześcijaninem i obdarowanie zbawieniem przez Jezusa Chrystusa nie czyni ich automatycznie doskonałymi. Tymczasem niebo jest stanem doskonałym, wypełnionym doskonałymi zbawionymi w doskonałej relacji z Bogiem i pomiędzy sobą. Jezus wyraźnie wymagał doskonałości od swoich uczniów: „Bądźcie doskonali jak doskonały jest Ojciec wasz niebieski” (Mt $5,48)$.

Jeśli człowiek ma posiąść niebo, potrzebuje doskonałości. Z takiej perspektywy czyściec wydaje się niezbędny, ponieważ to, co się tam dokonuje, gwarantuje realizację biblijnej obietnicy: „Ten, który zapoczątkował w was dobre dzie-

${ }^{48}$ Zob. S. Kałdon, Czyściec jako przejaw Bożego miłosierdzia, „Ruch Biblijny i Liturgiczny” 53(2000) 3-4, s. 216.

${ }^{49}$ Zob. Katolicki katechizm dorosłych. Wyznanie wiary Kościoła wydany przez Niemiecka Konferencję Biskupów, Poznań 1987, s. 408. 
ło, dokończy go do dnia Chrystusa Jezusa" (Flp 1,6), nawet gdyby w chwili śmierci biologicznej „dobre dzieło" nie zostało jeszcze ukończone.

Po stuleciach wiary w stan przejściowy po śmierci przyszedł czas, by nadać tej prawdzie wiary formalny kształt dogmatu. Sobór Lyoński II (1274) potwierdził pamięć Kościoła o zmarłych i możliwość niesienia im pomocy, zwłaszcza przez ofiarę Mszy św. ${ }^{50}$ Sobór Florencki w Dekrecie dla Greków z roku 1439 nadał nauce o czyśćcu rangę definicji ex cathedra ${ }^{51}$. Sobór Trydencki w Dekrecie o usprawiedliwieniu z roku 1547 podał dogmat o czyśćcu w następującym brzmieniu: „Jeśli ktoś twierdzi, że po otrzymaniu łaski usprawiedliwienia każdemu pokutującemu grzesznikowi odpuszczona jest wina i zgładzona kara wieczna w taki sposób, że nie pozostaje żadna doczesna kara do odpokutowania czy to na tym świecie, czy w przyszłym - w czyśćcu - przed wejściem do królestwa niebieskiego - niech będzie wyłączony ze społeczności wiernych" ${ }^{52}$.

Sobór Trydencki zalecił też biskupom i kapłanom, aby naukę o czyśćcu „przestrzegano, nauczano i wszędzie ją głoszono. Zagadnienia zaś dla prostego ludu trudniejsze i subtelniejsze, które nie służą do zbudowania i z których najczęściej nie ma żadnego pożytku dla pobożności - z kazań ludowych powinny być wyłączone" 53 .

Sobór Watykański II w Konstytucji dogmatycznej o Kościele Lumen gentium z roku 1964 potwierdził nauczanie wcześniejszych soborów, a zwłaszcza naukę o wstawiennictwie za zmarłych ${ }^{54}$. W Katechizmie Kościoła katolickiego naukę o czyśćcu ujęto tak: „Ci, którzy umierają w łasce i przyjaźni z Bogiem, ale nie są jeszcze całkowicie oczyszczeni, chociaż są już pewni swego wiecznego zbawienia, przechodzą po śmierci oczyszczenie, by uzyskać świętość konieczną do

\footnotetext{
${ }^{50}$ Wyznanie wiary cesarza Michała VIII Paleologa na Soborze Lyońskim II w roku 1274: ,Jeśliby prawdziwie pokutujący zakończyli życie w miłości [Boga] jeszcze przed godnym zadośćuczynieniem czynami pokutnymi za popełnione grzechy i zaniedbania, wówczas ich dusze - jak nam brat Jan [Parastron OFM] wyjaśnił - zostaną po śmierci oczyszczone aktami czyśćcowymi, czyli ekspiacyjnymi. Do złagodzenia tego rodzaju kar dopomaga wstawiennictwo wiernych żyjących, a mianowicie ofiary Mszy św., modlitwy, jałmużny i inne akty pobożności, które zgodnie z postanowieniami Kościoła jedni wierni zwykli ofiarować za innych wiernych”. Zob. Breviarum fidei, Poznań 1989, s. 596.

${ }^{51}$ „Jeśliby prawdziwie pokutujący zakończyli życie w miłości Boga jeszcze przed godnym zadośćuczynieniem czynami pokutującymi za popełnione grzechy i zaniedbania, wówczas dusze ich zostaną po śmierci oczyszczone karami czyśćcowymi. Do złagodzenia tego rodzaju kar dopomaga im wstawiennictwo wiernych żyjących, a mianowicie ofiary Mszy św., modlitwy, jałmużny i inne akty pobożności, które zgodnie z postanowieniami Kościoła jedni wierni zwykli ofiarować za innych wiernych". Zob. tamże, s. 601-602.

${ }^{5}$ Tamże, s. 330.

53 Tamże, s. 603.

54 „Uznając w pełni tę wspólnotę całego Mistycznego Ciała Jezusa Chrystusa, Kościół pielgrzymów od zarania religii chrześcijańskiej czcił z wielkim pietyzmem pamięć zmarłych, a ponieważ święta i zbawienna jest myśl modlić się za umarłych, aby byli od grzechów uwolnieni ( 2 Mch 12,46), także modły za nich ofiarował" (KK 50).
} 
wejścia do radości nieba. To końcowe oczyszczenie wybranych, które jest czymś innym niż kara potępionych, Kościół nazywa czyśćcem” (KKK 1030-1031).

Naukę Kościoła o czyśćcu można podsumować stwierdzeniem Soboru Trydenckiego: „Czyściec istnieje, a dusze tam zatrzymane są wspomagane wstawiennictwem wiernych" 55 .

\section{Refleksja teologiczna o czyśćcu}

Wokół czyśćca narosło wiele nieporozumień i niedomówień. Powodem tego stanu rzeczy może być fakt, że w Piśmie Świętym nie znajdziemy bezpośredniego potwierdzenia tej prawdy (a jedynie potwierdzenia pośrednie) oraz że ten artykuł wiary ma swe podstawowe źródło w Tradycji Kościoła.

W ciagu lat powstało wiele błędnych koncepcji czyśćca. Najważniejsze z nich są następujące:

- Czyściec jest trzecim, obok nieba i piekła, trwałym stanem eschatycznym.

- Czyściec jest drugą szansą na przyjęcie zbawienia od Chrystusa, po nieudanej pierwszej próbie podczas ziemskiego życia (Kościół uczy, że ostatecznego wyboru człowiek dokonuje w momencie śmierci).

- Czyściec jest przejściowym piekłem. W rzeczywistości jest stanem ku zbawieniu, początkiem, pierwszym doświadczeniem oraz drogą do nieba.

- Czyściec jest wynalazkiem wieków średnich, kiedy to duchowni chcieli lepiej kontrolować ludzi świeckich i nieźle dorabiać na wstawiennictwie ${ }^{56}$.

- Czyściec jest miejscem, gdzie dusze zarabiają na swoje zbawienie (de facto zbawienie jest łaską Bożą).

- Dusze w czyśćcu są obciążone winami. W istocie ich winy zostały już wcześniej odpuszczone albo sakramentalnie, albo przez żal doskonały. „Długiem" dusz w czyśćcu są kary jako konsekwencje zaciągniętych win. Jak długo pozostają nieodpokutowane, stanowią przeszkodę do pełnego zjednoczenia z Bogiem.

Kary czyśćcowe, to nie „wyłącznie prawnicze, [...] suche i bezduszne egzekwowanie litery prawa ze strony pamiętliwego i «obrażonego» Boga, który nie przestaje dopominać się zadośćuczynienia, ale środek leczniczy, który [...] służy przede wszystkim samemu człowiekowi, pozwalając mu połączyć się na powrót z Bogiem, wejść z Nim w doskonałą wspólnotę i radować się przyjaźnią z innymi’"57.

Człowiek po śmierci sam nie może już nic zrobić dla swego zbawienia, może natomiast biernie poddać się karze, która niesie oczyszczenie, a także korzystać z życzliwego wsparcia żyjących.

\footnotetext{
${ }^{55}$ Zob. Breviarum fidei, dz. cyt., s. 603.

${ }^{56}$ Zob. tamże, s. 603.

${ }^{57}$ Z. Kijas, Czyściec. Czy jest i dla kogo?, Kraków 1999, s. 246-247.
} 
Teologia katolicka uczy o dwóch rodzajach kar czyśćcowych:

- Kara czasowego odrzucenia (poena damni). Dusze zmarłych oczyszczają się przez to, że wiedza, iż są kochane przez Boga i będą Go posiadać na zawsze, ale aktualnie są pozbawione możliwości widzenia Go i obcowania z Nim. Tęsknota za Bogiem i ból niemożliwości złączenia się z Nim są ogromne, ponieważ dusza jest już wolna od przeszkód i rozproszeń, jakich doznawała na ziemi, i może całym swym naturalnym pragnieniem zwracać się ku Temu, który jest Miłością, a nie może do Niego dotrzeć. Ten ból oczyszcza duszę z egoizmu i innych przywar ${ }^{58}$.

- Kara zmysłów (poena sensus). Ojcowie Kościoła i teologowie uważają ją za konsekwencję nieuporządkowanych pożądań i przyjemności, jakich człowiek szukał za życia. W przeciwieństwie do kary czasowego odrzucenia - ta kara ma charakter „zewnętrzny”, a Biblia nazywa ją ogniem.

Paweł pisze o „ocaleniu jakby przez ogień” (1 Kor 3,15). Ojcowie i doktorzy Kościoła uważają że ten „ogień w czyśćcu nie jest przenośnią, ale ogniem prawdziwym, który pali i wzbudza boleść" ${ }^{59}$, zadaje cierpienie i wypala nieczystości. Ma on charakter oczyszczający. Nie jest to jednak ogień fizyczny, bo czyściec nie jest miejscem fizycznym, ale jakiś rodzaj ognia duchowego.

Kiedy złoto oczyszczone w ogniu ma 24 karaty, jest wtedy najczystszej próby i nie zawiera żadnych zanieczyszczeń i domieszek. Dusza jest jak złoto: im bardziej jest traktowana ogniem czyśćcowym, tym bardziej zbliża się do doskonałości i nic już nie stoi na przeszkodzie, aby dostapiła nieba.

Jest znamienne, że także w przypadku piekła autorzy biblijni mówią o ogniu („Idźcie precz ode Mnie, przeklęci, w ogień wieczny (to pyr to aiōnion), przygotowany diabłu i jego aniołom!”; Mt 25,41), ale tamten ogień, „to ogień duchowy zapalony gniewem Bożym"60, który ani nie oczyszcza, ani nigdy się nie kończy. Natomiast ogień czyśćcowy został rozpalony przez łaskę Bożej miłości i ma moc duszę oczyścić.

\footnotetext{
${ }^{58}$ Ilustracją może być objawienie prywatne s. Medardy (Zofii Wyskiel) z 1953 r.: „W czyśćcu dusze wiele cierpią. Cierpienie ich polega zwłaszcza na tej wielkiej tęsknocie za Bogiem. Bo to są dusze święte, są w stanie łaski Bożej i bardzo pragną już jak najrychlej być złączone z tą Przedwieczną Światłością, a nie mogą, bo jeszcze materia nieodpokutowanych kar ciąży na nich. Bóg również tęskni za nimi. Chciałby już je mieć u Siebie i cieszyć się w swojej chwale z nimi. Ale Jego Sprawiedliwość musi być wykonana, bo nic zmazanego nie może wejść do Królestwa Niebieskiego, niebieskiej chwały. Tęsknota ta jest tak straszna, że niczym jest ogień, niczym są inne cierpienia, tortury i męki wobec tęsknoty za Bogiem - Miłością, tym bardziej że dusza taka wie, że sama była powodem tego oddalenia, bo nie dbała tu na ziemi o to, aby stawać się coraz czystsza, by móc zaraz po śmierci złączyć się z Bogiem. Dusza nie zdaje sobie tu sprawy na ziemi, jak wielki jest Bóg, jak wielką Miłością On jest, poznaje Go jednak w chwili śmierci i dlatego tak bardzo cierpi z powodu tego oddalenia od Boga". Zob. http://www.mali-rycerze.pl/czytam,735 [dostęp 28.04.2015].

${ }^{59}$ Zob. Katarzyna z Genui, Rozprawa o czyśćcu, Wrocław 1998, s. 24.

${ }^{60}$ Zob. F. Kowalska, Dzienniczek, Warszawa 2011, s. 242 (nr 741).
} 
We współczesnej teologii coraz ostrożniej mówi się o samej naturze kar czyśćcowych, ponieważ są one osłonięte mgłą tajemnicy. „Ocalenie przez ogień" jest jakiegoś rodzaju karą dla ludzkich grzesznych zmysłów, w której przejawia się jednocześnie i sprawiedliwość Boga, i Jego miłosierdzie.

Wyraźnie się też mówi, że czyściec nie jest ani miejscem, ani też nie podlega czasowi. Na życie po śmierci nie wolno przenosić pojęć, którymi człowiek posługiwał się w doczesności. Po śmierci jest inaczej! Czyściec jest rzeczywistością wymykającą się czasowi, a jednak przejściową. Stan ten dobiegnie końca $\mathrm{z}$ chwila paruzji.

Prawdę o czyśćcu odrzucił Marcin Luter, a za nim protestanci. Luter uznał, że z ksiąg Pisma Świętego nie da się udowodnić istnienia czyśćca, a nadto, gdyby nawet jakieś dusze były w czyśćcu, w ogóle nie byłyby pewne swego zbawienia $^{61}$. Dzisiaj uważa się, że poglądy Lutra nie wynikały z pobudek dogmatycznych, tylko z trudnych do zaakceptowania praktyk religijnych (szafowania odpustami, Mszami i modlitwami za zmarłych) ${ }^{62}$. Powodem było też odrzucenie Drugiej Księgi Machabejskiej, w której znajduje się najmocniejszy biblijny argument za istnieniem czyśćca ${ }^{63}$.

Dzisiaj protestanci twierdzą, że gdyby rzeczywiście było potrzebne cierpienie za grzechy w czyśćcu, to tym samym ofiara Chrystusa byłaby niewystarczająca. Wiara w czyściec stanowi - ich zdaniem - zaprzeczenie wystarczalności ofiary przebłagalnej Chrystusa $\mathrm{i}$ jest sprzeczna z biblijną nauką o zbawieniu. Uznanie czyśćca jest równoznaczne z przyjęciem tezy, że ofiara Chrystusa jest niedoskonała, niekompletna i niewystarczająca.

Ustosunkowując się do tej kwestii, trzeba mieć świadomość, że zbawienie wymaga od człowieka transformacji: nie może się zjednoczyć ze świętym Bogiem ktoś, kto nie jest święty. Jaki los czeka więc tych, którzy dostapili darowania win od Chrystusa, ale przed śmiercią nie zdołali się gruntownie przekształcić?

${ }^{61}$ Zob. Leon X, Bulla „Exsurge Domine” (1520), w: Breviarium fidei, Poznań 2000.

${ }^{62}$ Zob. R. Porada, Czyściec - dojrzewanie do chwaty. Nauka o eschatologicznym stanie oczyszczenia $w$ dialogu luterańsko-rzymskokatolickim $w$ USA, w: Człowiek $w$ dialogu, red. Z. Glaeser, Opole 2012, s. 592.

${ }^{63}$ Druga Księga Machabejska jest częścią greckiej Septuaginty, czyli Biblii używanej przez Żydów. Dla starożytnych chrześcijan miała ona rangę Pisma Świętego, dlatego nie dziwi, że 80\% cytatów Starego Testamentu w Nowym jest w wersji Septuaginty, w tym nawet cytat z 2 Mch 7 w Hbr 11,35b. Najstarsze synody kościelne (np. rzymski w roku 382) włączyły Drugą Księge Machabejską do kanonu pism chrześcijańskich. Tekst o modlitwie za zmarłych w 2 Mch 12,32-45 zrodził u Żydów praktykę takiej modlitwy, która odmawiana jest także dzisiaj jako „Kaddisz za zmarłych". Do codziennej modlitwy za zmarłego ojca był (i jest) przez rok zobowiązany syn. Gdy ojciec nie miał syna albo nie był pewien, że wywiąże się on ze zobowiązania, w testamencie pozostawiał pieniądze dla kogoś, kto będzie się za niego modlił. Zob. G. Anderson, Is purgatory biblical?, dz. cyt., s. 43. Drugą Księgę Machabejską, z której inspirację wiary czerpali Żydzi i starożytni chrześcijanie, protestanci wyłączyli ze swojego kanonu biblijnego. 
Trzeba pamiętać, że zbawienie rozgrywa się na dwóch poziomach:

- Bóg usprawiedliwia człowieka (czyli daruje mu winy).

- Bóg dokonuje jego transformacji, czyli go uświęca i doskonali (przy jego współpracy).

Samo przebaczenie grzechów, czyli usprawiedliwienie, nie wystarcza do zbawienia. To jest dopiero pierwszy krok. Potrzeba uświęcenia człowieka, a to nie jest proces natychmiastowy, ale rozciagnięty w czasie. Jeśli człowiek nie jest uformowany w świętości i nie jest ugruntowany w doskonałości, nie może zjednoczyć się z Bogiem w niebie. Może to nastapić dopiero wtedy, gdy przemiana, która rozpoczęła się w chrzcie, dobiegnie do samego końca.

Ofiara Chrystusa wymaga współpracy człowieka. Dopiero wtedy dokonuje się uświęcenie i przemiana człowieka. W Biblii można znaleźć wiele ilustracji tej prawdy. Kiedy na przykład Dawid jako król Izraela uwiódł Batszebę i polecił zamordować jej męża, przybył do niego wkrótce prorok Natan. Dawid przyznał się do winy, a prorok ogłosił jej wybaczenie i uchylił wyrok śmierci, na jaki król zasłużył: „Pan odpuszcza ci twój grzech - nie umrzesz” (2 Sm 12,13). Wybaczenie nie oznaczało jednak anulowania kary, na jaką Dawid zasłużył i którą musiał odpokutować. Bóg bowiem nie był zainteresowany jedynie jego uniewinnieniem. Chciał dokonać transformacji osoby Dawida i kazał mu zmierzyć się z konsekwencjami swojego czynu.

Dawid ponosił przez całe życie przykre następstwa swego grzechu. Wystarczy tylko wspomnieć ucieczkę króla z Jerozolimy z powodu syna Absaloma. Dawid dał wtedy wyraz swej duchowej nędzy, mówiąc: „Jeżeli Pan będzie mnie darzył życzliwością, to przywróci mnie, tak że znów będę mógł zobaczyć Arkę Bożą razem z przybytkiem. Jeżeli jednak powie: «Nie znajduję w tobie upodobania» - oto jestem - niech czyni ze mną, co uzna za słuszne!" (2 Sm 15,25-26).

Kiedy indziej Dawid został obrzucony kamieniami przez Szimei i przeklęty słowami: „Precz, precz, krwawy człowieku i niegodziwcze!” (2 Sm 16,7), a król pokornie to znosił. Takich przykładów w życiu Dawida było wiele. Bóg wybaczył mu grzech, ale król rozumiał, iż wybaczenie wymaga cierpliwej naprawy tego, co zepsuł, i że ból, który cierpiał, jest niczym innym jak logiczną konsekwencją popełnionych czynów.

Zbawienie nie ogranicza się do jednorazowego doświadczenia usprawiedliwienia. Wymaga stopniowej moralnej i duchowej przemiany. Doświadczał jej Dawid, kiedy przeżywał swój czyściec, przynajmniej w ziemskim wymiarze. Rola Dawida w tym procesie naprawy jest wyraźnie pasywna: doświadczenia spadały na niego, a on się im poddawał i pozwalał się kształtować.

W Biblii znajdziemy też przykłady bardziej aktywnej roli grzesznika, który otrzymując przebaczenie u Boga, zostaje zobowiązany do spłaty zaciągniętych długów przez pełnienie uczynków miłosierdzia. Klasycznym przykładem może być historia króla Nabuchodonozora. Kiedy król uznał swoje winy i skruszony 
prosił Daniela o wskazówki, jak je naprawić, usłyszał: „Królu, przyjmij moją radę i okup swe grzechy uczynkami sprawiedliwymi, a swoje nieprawości miłosierdziem nad ubogimi" (Dn 4,24).

O ile transformacja Dawida miała charakter bardziej bierny, o tyle Nabuchodonozora ma mieć charakter czynny: król babiloński ma okupić popełnione zło jałmużną na rzecz ubogich. Autor biblijny wyraźnie wskazuje „uczynki sprawiedliwe" jako drogę do pełnego zbawienia.

Moc dobrych czynów i udzielanej jałmużny ilustruje też przykład Tabity z Dziejów Apostolskich (Dz 9,36-42). Kiedy zmarła ta dobra kobieta, jej martwe ciało otoczyły wdowy i pokazywały Bogu chitony i płaszcze, które zrobiła im za swego życia. Siła dobrych uczynków Tabity wraz z modlitwą Piotra przywróciły jej życie.

Przytoczony przykład króla Dawida wskazuje, że przebaczenie i zbawienie jest czymś więcej niż tylko jednorazowym zdjęciem winy z grzesznika. Wymaga długotrwałego procesu przemiany człowieka, a więc zadania, które w chwili śmierci jest zwykle jeszcze niedokończone. Ta przemiana, uświęcenie i postęp w doskonałości mogą być przyspieszone, na przykład przez dawanie jałmużny, jak ilustruje to rada udzielona Nabuchodonozorowi przez proroka Daniela. Jednocześnie zaś już tu, na ziemi, można kształtować skarbiec swoich zasług, które będą pomocą dla człowieka po śmierci (Tabita) ${ }^{64}$.

Jakkolwiek ofiara Chrystusa jest doskonała, kompletna i wystarczająca, to wyraźnie wymaga zaangażowania człowieka. Jeśli to zaangażowanie za życia okaże się niewystarczające, będzie musiało być kontynuowane już po śmierci. Rozumieli to ludzie wierzący, modląc się i składając ofiary za zmarłych. Czynili to, zanim jeszcze zaczęła się wyraźniej krystalizować myśl o czyśćcu. Ta myśl jest w Biblii wyraźna, chociaż nie jest wyrażona bezpośrednio. Występuje również w pouczeniach, że osobiste cierpienia i osobiste zasługi mają wielkie znaczenie dla losu człowieka po śmierci.

„Kościół od początku czcił pamięć zmarłych i ofiarował im pomoce, a w szczególności Ofiarę eucharystyczną, by po oczyszczeniu mogli dojść do uszczęśliwiającej wizji Boga. Kościół zaleca także jałmużnę, odpusty i dzieła pokutne za zmarłych"65, modlitwę i Msze gregoriańskie. Z myślą o pomocy duszom zmarłych jest obchodzony w Kościele od roku 998 (w Polsce od XII w.) Dzień Zaduszny.

W duchu nauki o obcowaniu świętych teologowie uważają, że można się modlić nie tylko za dusze czyśćcowe, ale także do nich z prośbą o wstawiennictwo. Dusze te bowiem kochają Boga i mogą się modlić, a więc mogą też wypraszać żyjącym pomoc ${ }^{66}$.

\footnotetext{
${ }^{64}$ Zob. G. Anderson, Is purgatory biblical?, dz. cyt., s. 42.

${ }^{65}$ KKK 1032.

${ }^{66}$ Zob. W. Granat, Dogmatyka katolicka. Synteza, dz. cyt., s. 505.
} 
Z problematyką czyśćca wiąże się kwestia odpustów, ale to już inne zagadnienie, wymagające odrębnego opracowania.

\section{"The person will be saved, but only as through fire" (1 Cor 3:15). Purgatory from the Perspective of the Bible and in Theological Reflection}

\section{Summary}

Apart from the two final states after death, heaven and hell, there is a third transitional state called "purgatory". The Church believes in it, though this term does not occur in the Bible.

The aim of this paper is to present scriptural sites relating to purification after death. There are only a few texts that concern purgatory and in addition they do not point directly to it: 2 Macc 12:38-45 (prayers and atonement can help the dead), Matt 12:31-32 (certain offenses can be forgiven in the age to come) and 1 Cor 3:10-15 (there is a cleansing fire after death - different from the punishment of the damned). The message of these texts is clear: the lot of a man may be changed even after death.

One can also find in the Sacred Scripture some metaphors applying to purgatory: whipping (Lk 12:47-48), imprisonment for debts (Matt 5:25-26) and leaving the netherworld (Matt 12:4). Some scholars think, the Jesus' parable of the rich man and Lazarus (Lk 16:19-31) also reveals the mystery of the final purification.

Although the Church believed in purgatory from the very beginning, she formulated her doctrine of faith on purgatory especially at the Councils of Florence (1439) and Trent (1547). What the Church teaches is that there is a purification that occurs after death for all who die in God's friendship but who have not been sufficiently purified for the glory of heaven. The purification can involve some kind of pain or discomfort (poena damni - punishment of temporary rejection and poena sensus - punishment of the senses).

Martin Luther and the Protestants reject the doctrine of purgatory. They argue that if a man had to suffer in purgatory, the sacrifice of Jesus Christ would be incomplete and insufficient. The Catholic answer to the dilemma is that salvation assumes two steps: forgiveness of sins and transformation of life. The former occurs immediately, the latter needs time. God changes people and actually makes them righteous. Only when they are entirely sanctified and fully perfected, they are truly fit to enjoy the beatific vision of heaven. And what about people who die before they have been thoroughly transformed?

The Catechism of the Catholic Church (1032) encourages the faithful on earth to assist those being purified and to offer prayers, above all the Eucharistic sacrifice, almsgiving, indulgences, and works of penance undertaken on behalf of the dead.

\section{Keywords}

afterlife, particular judgment, purgatory, final purification, prayer for the dead

\section{Słowa kluczowe}

życie pozagrobowe, sąd szczegółowy, czyściec, końcowe oczyszczenie, modlitwa za zmarłych 


\section{Bibliografia}

\section{Literatura poszerzająca zagadnienie}

Anderson G., Is purgatory biblical? Beginning with David's penitence. Gary A. Anderson shows the Scriptural structure of purgatory, „First Things” 217(2011), s. 39-44.

Atwell R., From Augustine to Gregory the Great. An evaluation of the emergence of the doctrine of purgatory, „Journal of Ecclesiastical History” 38(1987) 2, s. 173-86.

Basiuk M., Pismo Święte o czyśćcu, „Nasza Myśl” 10(2013) 37, s. 8-9.

Bietenhard H., Kennt das Neue Testament die Vorstellung vom Fegefeuer?, „,Theologische Zeitschrift" 3(1947) 2, s. 101-22.

Boulding C., Purgatory. What do Catholics believe, „Epworth Review” 22(1995) 2, s. 101-109.

Brattston D., Hades, hell and purgatory in ante-Nicene Christianity, „Churchman” 108(1994) 1, s. 69-79.

Campbell J., Forgiveness in the age to come, (1-2), „Affirmation \& Critique” 9(2004) 1, s. 56-69; 2, s. 78-95.

Casey J., After lives. A guide to heaven, hell, \& purgatory, Oxford 2010.

Chrostowski W., Niebo, piekło i czyściec w perspektywie biblijnej, w: Niebo, piekło, czyściec. Spojrzenie Kościoła. Praca zbiorowa, red. K. Czapla, P. Góralczyk. Zakopane-Ząbki 2010, s. 27-54.

Granat W., Biblia oparciem nauki o czyśćcu, w: Ku człowiekowi i Bogu w Chrystusie. Zarys dogmatyki katolickiej, t. 2, Lublin 1974, s. 519-521.

Horne B., Where is purgatory, San Francisco 1988, s. 92-100.

Jugie M., Purgatory and the means to avoid it, Westminster, Md 1949.

Kałdon S., Czyściec jako przejaw Bożego miłosierdzia, „Ruch Biblijny i Liturgiczny” 53(2000) 3-4, s. 213-222.

Kaszowski M., Niebo, piekło, czyściec i to, co nastapi na końcu. Synteza eschatologii, Katowice-Mikołów 2009.

Kijas Z., Niebo w domu Ojca, czyściec dla kogo, piekło w oddaleniu, Kraków 2010.

Kinast R., The pope, purgatory, and process theology, „Encounter” 73(2013) 3, s. 39-46.

Klinkowski J., Dlaczego modlimy się za zmartych?, „Legnickie Wiadomości Diecezjalne" 20(2011) 3, s. 98-107.

Langemeyer G., Himmel, Hölle, Fegefeuer. Was erwartet der Christ nach dem Tod?, Freiburg 1990, s. 78-92.

Lanne E., The teaching of the Catholic Church on purgatory, „One in Christ” 28(1992) 1, s. 13-30.

McGuire B., Purgatory, the communion of saints, and medieval change, „Viator” 20(1989), s. 61-84.

Merkt A., Das Fegefeuer. Entstehung und Funktion einer Idee, Darmstadt 2005.

Ombres R., The doctrine of purgatory according to St Thomas Aquinas, „Downside Review" 99(1981) 337, s. 279-287.

Ombres R., The theology of purgatory, Dublin 1980. 
Perry A., Purgatory. The logic of total transformation, „Wesleyan Theological Journal” 48(2013) 1, s. 205-207.

Porada R., Czyściec - dojrzewanie do chwaty. Nauka o eschatologicznym stanie oczyszczenia $w$ dialogu luterańsko-rzymskokatolickim w USA, w: Człowiek dialogu. Księga pamiatkowa dedykowana księdzu arcybiskupowi Alfonsowi Nossolowi z okazji 80. rocznicy urodzin, 55. rocznicy święceń kaptańskich oraz 35. rocznicy święceń biskupich, red. Z. Glaeser, Opole 2012, s. 587-605.

[Salij J.] js, Ogień czyśćcowy, „W Drodze” 19(1991) 11, s. 108-112.

Salkeld B., Can catholics and evangelicals agree about purgatory and last judgment?, New York 2011.

Stackhouse J., The hard work of holiness. Protestants and purgatory, „Christian Century” 131(2014) 12, s. 26-29.

Stępień J., Nauka św. Pawła o śmierci, „Ruch Biblijny i Liturgiczny” 15(1962) 5, s. 283$-291$.

Swanson R., The burdens of purgatory, w: Medieval Christianity, red. D. Bornstein, Minneapolis 2009, s. 353-380, 396-397.

Townsend J., 1 Corinthians 3:15 and the school of Shammai, „Harvard Theological Review" 61(1968) 3, s. 500-504.

Walls J., Purgatory. The Logic of Total Transformation, Oxford 2012.

Wronka S., Eschatologiczna kara w $Ł k$ 12,47-48a (nowotestamentowy argument na rzecz czyśćca?), „Zeszyty Naukowe Stowarzyszenia Biblistów Polskich” 2(2005), s. 263-290 . 